\title{
'n Handleiding uitsluitlik op die skryfkuns gerig
}

\begin{tabular}{|c|c|}
\hline \multicolumn{2}{|c|}{$\begin{array}{l}\text { Book Title: } \\
\text { Die Afrikaanse skryfgids }\end{array}$} \\
\hline \multicolumn{2}{|l|}{ Book Cover: } \\
\hline \multicolumn{2}{|c|}{ 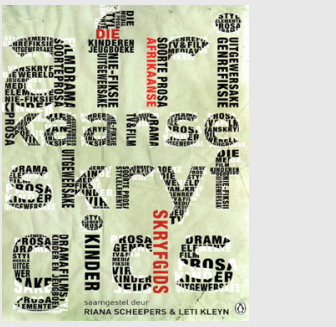 } \\
\hline \multicolumn{2}{|c|}{$\begin{array}{l}\text { Authors: } \\
\text { Riana Scheepers \& Leti Kleyn }\end{array}$} \\
\hline \multicolumn{2}{|c|}{$\begin{array}{l}\text { ISBN: } \\
\text { 978-0-14-353015-2 }\end{array}$} \\
\hline \multicolumn{2}{|c|}{$\begin{array}{l}\text { Penguin Books, Johannesburg, } \\
\text { 2012, } 458 \text { p., ZAR170.00* } \\
\text { *Book price at time of review }\end{array}$} \\
\hline \multicolumn{2}{|c|}{$\begin{array}{l}\text { Review Title: } \\
\text { "n Handleiding uitsluitlik op } \\
\text { die skryfkuns gerig' }\end{array}$} \\
\hline \multicolumn{2}{|c|}{ Reviewer: } \\
\hline \multicolumn{2}{|l|}{$\begin{array}{l}\text { Affiliation: } \\
\text { Private }\end{array}$} \\
\hline \multicolumn{2}{|c|}{$\begin{array}{l}\text { Email: } \\
\text { helenedk@mweb.co.za }\end{array}$} \\
\hline \multicolumn{2}{|c|}{$\begin{array}{l}\text { PostNet Suite 1064, } \\
\text { Midstream Estate, Private } \\
\text { Bag X1007, Lyttelton 0140, } \\
\text { South Africa }\end{array}$} \\
\hline \multicolumn{2}{|c|}{$\begin{array}{l}\text { How to cite this book review: } \\
\text { De Kock, H., 2013, "n } \\
\text { Handleiding uitsluitlik op die } \\
\text { skryfkuns gerig', Literator } \\
\text { 34(2), Art. \#1063, } 2 \text { pages. } \\
\text { http://dx.doi.org/10.4102/ } \\
\text { lit.v34i2.1063 }\end{array}$} \\
\hline \multicolumn{2}{|c|}{$\begin{array}{l}\text { Copyright: } \\
\text { (C) 2013. The Authors. } \\
\text { Licensee: AOSIS } \\
\text { OpenJournals. This work } \\
\text { is licensed under the } \\
\text { Creative Commons } \\
\text { Attribution License. }\end{array}$} \\
\hline \multicolumn{2}{|l|}{ Read online: } \\
\hline 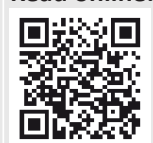 & $\begin{array}{l}\text { Scan this QR } \\
\text { code with your } \\
\text { smart phone or } \\
\text { mobile device } \\
\text { to read online. }\end{array}$ \\
\hline
\end{tabular}

Uiteindelik het ons vir die eerste keer 'n omvattende, algemene handleiding in Afrikaans wat in sy geheel oor die skryfkuns gaan. Hier is 'n handboek wat hoofsaaklik oor die totstandkoming van 'n teks handel.

Dié werk poog om die massa vrae wat in die kollektiewe skrywersgemoed opkom te beantwoord. Die term skrywersgemoed kan gekwalifiseer word. Die aspirantskrywer worstel voortdurend met onsekerhede en selfs die mees ervare skrywer se kreatiwiteit kan hom of haar op 'n dwaalspoor lei. Skryf is inderdaad ' $n$ tasting in die duister. Om die werklikheid in enige genre te representeer, bly kompleks. Nou kom hierdie omvattende werk wat feitlik al die onsekerhede bekwaam aanroer. Dit is ' $n$ welkome handleiding, saamgestel deur twee skrywers, Riana Scheepers en Leti Kleyn.

Om 'n werk van dié omvang binne 'n beperkte ruimte te resenseer, is onmoontlik. Die boek behoort eerstens holisties beskou te word. Die Afrikaanse skryfgids is presies wat dit voorgee om te wees - 'n uitgebreide handleiding wat skrywers van algemene praktiese raad bedien om uiteindelik 'n teks voort te bring. Die werk is prakties gestruktureer sodat die basiese aspekte van die skryfkuns eerste aangeraak word. 'n Grondslag word gelê vir die skryfproses, asook die gebruik van die stylelemente. Vervolgens word haas alle onderwerpe aangaande die skryfkuns gedek. Van kreatiwiteit, skrywersmites, stylelemente, die prosa en die poësie, reisverhale, e-boeke en draaiboeke tot bloggers en vele ander aspekte van die skryfkuns word bespreek. Van die mees basiese kennis nodig vir die skryf van 'n verhaal, tot inligting oor hoe om uitgewers te nader word behandel. Selfs digitale boeke word in detail bespreek.

Die handleiding belig teoretiese perspektiewe aangaande die skryfkuns sowel as die praktiese aspekte van die skryfpraktyk. 'n Beswaar sou kon wees dat nie al die bydraes in verband met die skryfpraktyk op dieselfde vlak is nie. Dit sou 'n wanpersepsie wees, aangesien sommige bydraes die teoretiese aspekte van die skryfkuns aanraak en ander uitsluitlik op die skryfpraktyk gerig is. Die basiese geheim van goeie skryfwerk is immers om kennis te neem van inligting wat die skryfproses kan vergemaklik. So kan 'n skrywer leer om helder en eenvoudig te verwoord. Die handleiding gee effektief leiding om juis dít te doen.

Die skryfkuns as vakgebied word in hierdie broodnodige boek trouens so deeglik van alle kante af deurtrap, dat dit feitlik onmoontlik is om kritiek te lewer. 'n Mens kan wel kritiek lewer teen die beperkte omvang van die werk, aangesien elke onderwerp inderdaad 'n eie boek verdien. Geen dieper ontginning van onder andere die stylelemente en 'n genre soos die poësie vind plaas nie. Binne die bestek van 'n algemene handleiding is dit egter nie moontlik nie.

Elkeen van die sewentig plus bydraes verdien 'n resensie. Elke bydraer ken sy of haar aspek van die skryfkuns uitstekend. Verder is daar by die meeste bydraes 'n kritiese bewussyn van eie praktyk te bespeur. Dié gesoute bydraers ken al die slaggate en wys onomwonde daarop dat die praktiese raad in hierdie handleiding geen waarborg vir sukses is nie. Net die skrywer se eie talent en toewyding sal die deurslag gee. Lizette Rabe stel in haar bydrae oor die meganika van die tydskrifartikel duidelik dat kreatiwiteit dissipline voorveronderstel.

Sommige bydraes kan uitgesonder word - wat nié beteken dat die ander nie bespreking verdien nie. Elke bydrae in hierdie handleiding is verantwoord. Chanette Paul se uitstekende uiteensetting van die stylelemente, perspektief en fokalisering asook dialoog is een voorbeeld hiervan. Min skrywers kan sake so deeglik soos Paul verwoord wanneer dit by die skep van 'n manuskrip kom.

Jeanette Ferreira lê duidelik klem op die verskil tussen wys en vertel, en gesels onderhoudend oor die versorging van manuskripte, 'n belangrike aspek wat dikwels deur aspirantskrywers verwaarloos word. Ervare digters soos byvoorbeeld Hans du Plessis, Louis Esterhuizen en Henning Pieterse lewer, bydraes oor die kompleksiteite en geheime van die poësie. Bernard Odendaal (2012:186) stel onder andere die volgende oor die vrye vers: 'Oewerlose moontlikhede; ongekende uitdagings'. Nie net die digkuns nie, maar ook die media bied uitdagings wat knap deur joernaliste soos Murray La Vita en Willemien Brümmer vasgevat word. Melt Myburgh 
skryf keurig en bondig oor die kuns van blogging. Jaco Jacobs, Fanie Viljoen en ander skrywers en illustreerders, bespreek die kinder- en jeugboeke kundig. Franci Greyling en Anneretha Combrink gee ' $n$ interessante perspektief op gemeenskapseie woordkuns en Johan Bakkes sê sy sê oor die vergoeding en belasting wat ter sake is.
Hierdie boek maak wêrelde vir skrywers oop. Die samestellers en álle bydraers kan hulself gerus op die skouer klop daaroor.

\section{Literatuurverwysings}

Odendaal, B., 2012, 'Vrye vers vs. tradisionele vorme', in R. Scheepers \& L. Kleyn (reds.) Die Afrikaanse skryfgids, ble. 182-187, Penguin, Johannesburg. 